\title{
O TEXTO COMO LÁPIDE
}

\section{Resenha}

\section{Berta Waldman*}

“Tudo nesse livro é invenção, mas quase tudo aconteceu”. Essa advertência dirigida ao leitor na apresentação de $K$, de Bernardo Kucinski ${ }^{1}$, merece interpretação. Se quase tudo aconteceu, por que lê-lo como ficção, quando o autor é um reconhecido jornalista? Ele próprio responde comunicando que não utiliza fontes, a não ser o arquivo de sua memória, depósito de acontecimentos mesclados com sentimentos, decifrados com o preenchimento das lacunas e com soluções inventadas para fazer frente aos bloqueios involuntários. Trata-se, pois, de um testemunho e uma denúncia . Se o desaparecimento de sua irmã Ana Rosa Kucinski - constitui a matéria originária do livro, é a vivência dessa supressão por parte de seu pai -identificado como 'K.' - que compõe o núcleo da obra. Uma escolha narrativa difícil, cuja matéria se define pela exibição de um abismo, de uma vertiginosa negatividade.

Curiosamente, o primeiro livro de Natalia Ginzburg, Léxico familiar, ${ }^{2}$ inicia com uma advertência similar: “... embora extraído da realidade, acho que deva ser lido como se fosse um romance”. Também ela declara que escreveu apenas aquilo de que se lembrava. Assim, se for lido como um relato, uma crônica da realidade, despontam as lacunas que o livro realmente apresenta, mas se for lido como um romance, não se pode dele exigir mais ou menos do que oferece, vislumbres e estilhaços de tudo que se vê e se ouve.

Os dois romances têm em comum o fato de retratarem períodos conturbados e terríveis da História. Enquanto Bernardo Kucinski expõe os crimes da ditadura militar brasileira (19641985 ), Natália Ginsburg apresenta um circuito familiar no qual os traços mais peculiares do fascismo parecem se congelar.

O conflito ao redor do qual se organiza o romance $K$ alude também a Franz Kafka e ao eixo de suas narrativas, que lançam o leitor para a sem-razão de um mundo fantasmático; afinal, o ponto seco do título tem o poder de antecipar o clima de absurdo que atravessa o

\footnotetext{
* Professora titular aposentada da Universidade de São Paulo e professora aposentada da Universidade Estadual de Campinas.

1 Bernardo Kucinski, K. São Paulo: Editora Expressão Popular, 2011. Ilustrações Ênio Squeff.

2 Natalia Ginzburg, Léxico Familiar. Trad. Homero Freitas Andrade. Rio de Janeiro: Paz e Terra, 1988.
} 
relato. Mas ao referir o universo sem sentido característico do autor tcheco, $\mathrm{K}$ aponta para o pai do autor e de Ana Rosa, Meir Kucinski, ele próprio ficcionista e especialista no idioma ídiche, que é quem protagoniza o processo de busca da filha e do genro, desaparecidos durante a ditadura militar.

O movimento permanente do pai idoso na busca do paradeiro do casal mantém o romance em suspensão, como que paralisado num ponto que não apresenta saída possível. Isso porque o casal não aparece em nenhum momento, embora seja permanentemente referido. Como estão mortos desde o início, a narrativa os mantém num ponto cego e semeia um vazio cavocado devagar e sempre, gerando uma angústia crescente no leitor, impossibilitado de se sustentar sobre qualquer ilusão relativa à sobrevivência do casal. $\mathrm{O}$ caminho vai sendo minado porque não se consegue enxergar nenhuma perspectiva positiva, alguma luz, num texto paradoxalmente composto e escrito de forma límpida. Desse modo, o ponto de vista que organiza a narrativa equilibra-se numa espécie de ponto de cegueira responsável pelo sentido último do que lemos. Mas concomitante com o ponto cego, o livro ilumina diferentes pontos de vista, que perfazem os diversos segmentos da ditadura militar no Brasil, trazidos à tona pelos caminhos da busca do pai. São esses rumos, independentes entre si, que dão substância à matéria sobre a qual se ocupa o livro e que tem como ponto nuclear o desaparecimento de Ana Rosa e Wilson Silva, em abril de 1974. Eles continuam 'desaparecidos' até hoje, ainda que tenha sido encontrado um registro nos arquivos do Departamento de Ordem Política e Social (Dops) paulista, atestando a data da prisão, sem mais informações. Ambos tinham 32 anos quando foram sequestrados pelas forças de segurança, no centro de São Paulo.

Ana Rosa era, além de militante política, professora doutora do Instituto de Química da Universidade de São Paulo e, devido ao seu desaparecimento, foi demitida por "abandono de emprego". Trata-se de um lamentável episódio da história da USP, pelo qual a instituição pediu desculpas tardias, sem, contudo, identificar os responsáveis pela torpe medida.

Depois de cerca de 10 dias sem receber um telefonema da filha que costumava chamálo semanalmente, o pai estranha a quebra de hábito e lhe telefona, mas não a encontra. Aí inicia seu processo de busca, justo no capítulo intitulado "Sorvedouro de pessoas". 3 Ela não está em casa, não atende ao telefone, está ausente do trabalho. K. começa a se preocupar. Em

\footnotetext{
${ }^{3}$ Ver p.19.
} 
busca de sinais da filha, ele perfaz caminhos estranhos e desconhecidos, enquanto vão se iluminando fragmentos da vida dela, que ele sequer imaginava: sua militância política clandestina, o casamento, novos amigos, as fotos com a família do marido, suas idas para o interior, onde se juntava a novos parentes e amigos. A ausência da filha, ao invés de afastá-la, aproxima-a do pai, na medida em que ele fica sabendo de coisas em relação a ela das quais nem desconfiava. O paradoxo trágico desse desencontro é que ele é também um encontro, uma revelação, porém, tardia; já morta, o pai vê a filha de corpo inteiro.

A tragédia já avançara inexorável quando, naquela manhã de domingo, K. sentiu pela primeira vez a angústia que logo o tomaria por completo/.../E como não perceber o tumulto dos novos tempos, ele escolado em política? Quem sabe teria sido diferente se, em vez dos amigos escritores do ídiche, essa língua morta que só poucos velhos ainda falam, prestasse mais atenção ao que acontecia no país naquele momento ${ }^{4}$

O narrador em terceira pessoa, como se pode perceber a partir do exemplo acima, está colado no personagem; assim, ao informar o que está acontecendo, ele transfere para a linguagem os sentimentos de apreensão, de angústia fina que vão tomando conta do personagem, transformando o discurso indireto em indireto livre, isto é, um discurso em que as vozes do narrador e do personagem se mesclam. Esse recurso transfere ao livro uma espessura de sentimentos e de impressões de forte impacto.

A filha confiara na outra família, não nele. Para a outra família, o casamento não fora secreto, apenas discreto. Havia nisso um significado maior, teria ela realizado uma troca de famílias? Esse pensamento o machucava. Teria sido uma resposta ao seu segundo casamento com aquela alemã que a filha detestava? Ou à sua devoção tão intensa à língua ídiche? Uma língua que nem ela nem os irmãos sabiam falar - aliás, por culpa dele, que não se preocupou em lhes ensinar. ${ }^{5}$

A saga do velho pai segue os caminhos do bom senso: dar queixa na Secretaria dos desaparecidos, consultar advogados, ir à casa do Padre Chico, buscar conhecidos na Polícia, no Exército, no SNI, no Instituto Médico Legal, seja onde for "dentro daquele sistema que engolia pessoas sem deixar traços" $6 \mathrm{O}$ pai, obcecado, passa a contar a todos o desaparecimento da filha, ampliando suas consultas e fabulações. Vai inclusive à reunião convocada pelo arcebispo de São Paulo, Dom Paulo Evaristo Arns, para contar sua história e ouvir a de outros desaparecidos políticos, todos querendo enterrar seus mortos.

\footnotetext{
${ }^{4}$ P. 19

${ }^{5}$ P.48.

${ }^{6}$ P.23.
} 
K. tudo ouvia, espantado. Até os nazistas, que reduziam suas vítimas a cinzas, registravam os mortos. Cada um tinha um número, tatuado no braço. A cada morte, davam baixa num livro./.../Não havia a agonia da incerteza. Eram execuções em massa, não era um sumidouro de pessoas. ${ }^{7}$

O inferno da busca passa pelo caminho vil e obsceno dos informantes da polícia, espias, um rabino, um dirigente da comunidade judaica no Rio de Janeiro, que supostamente mantinham contatos com generais. Em certo momento, a realidade se impõe definitiva: o casal era militante da resistência e ambos tinham sido sequestrados, torturados e assassinados. Talvez na "Casa da Morte”, em Petrópolis? Não se sabe.

O relato inclui uma carta de Ana Rosa destinada a uma amiga. Ela, que tem uma presença indireta no romance, apresenta-se, em primeira pessoa e conta que havia assistido a um filme, que ambas já haviam visto juntas: o Anjo Exterminador, de Buñuel. Estabelece, então, uma analogia entre as personagens que não conseguiam sair, sem motivo algum, presas que estavam numa prisão imaginária e ela própria, que sente o perigo rondando, a prisão diária de colegas no campus da Universidade. Como sair disso? Ela não sabe, apesar de se dar conta da sensação. A questão de abandonar a luta armada será retomada na parte final do livro:

antes havia algum sentido no que fazíamos, agora não há mais; aí é que entra o filme de Buñuel, aquelas pessoas todas podendo sair e ao mesmo tempo não podendo, não conseguindo, sem que haja um motivo, uma explicação racional. ${ }^{8}$

$\mathrm{Na}$ última etapa da busca, $\mathrm{K}$ dirige-se a um quartel que conhecia havia mais de cinquenta anos. Nunca imaginou que um dia o visitaria, levando cigarros e chocolates para os presos políticos. Esse quartel, antes uma pequena guarnição, era passagem de K. e seu irmão mais velho, quando recém-chegados a São Paulo, mascateavam mercadorias à prestação. Enquanto caminha pela prisão, K. rememora o tempo de sua própria prisão na Polônia, quando o arrastaram acorrentado pelas ruas de Wloclawek, para humilhá-lo publicamente. Lá participara da fundação de um partido sionista de esquerda, motivo de seu confinamento. Numa dobra de memória, o velho se vê a si mesmo preso na Polônia e sua mãe lhe trazendo as comidas de Pessach. Voltando ao presente, os presos armam um círculo com cadeiras e K, senta-se à frente. Começa a contar a história da filha, mas não tem mais energia; começa a

\footnotetext{
${ }^{7}$ P.27.

${ }^{8}$ P.51.
} 
soluçar, tenta distribuir os pacotes, mas cai. Os presos o levam a outra sala e o deitam. K. avista atrás dos presos,

a familiar janelinha gradeada da cela trazendo de fora promessas de sol e liberdade. Sentiu-se em paz. Muito cansado, mas em paz. Estendeu aos presos o pacote de cigarros. Depois , suas mãos se abriram e seus olhos se cerraram. ${ }^{9}$

A busca do velho K. chega ao fim. Mas não o livro, que inclui, a modo de fecho, a "Mensagem ao companheiro Klemente", sucessor de Carlos Marighella na direção da ALN (Ação Libertadora Nacional), um dos principais grupos de luta armada contra a ditadura militar. Nessa mensagem assinada por Rodriguez, revela-se uma avaliação do movimento que inclui discordância em relação à afirmação de Klemente ao grupo de Paris segundo a qual a "Organização" não existe mais. Rodrigues afirma que para a repressão a "Organização" sim existe, pois continua capturando companheiros e, os que caem, somem. Mas, se a luta está perdida, por que se deixarem liquidar pela ditadura? Em síntese, a mensagem contém um elenco de discordâncias, de erros e a necessidade de por fim à luta armada. Se a luta tivesse sido suspensa em tempo, vidas teriam sido poupadas. Além disso, segundo se diz, os companheiros teriam incorporado o método de terror da própria ditadura, executando, por exemplo, aqueles que falaram sob tortura, como se fosse possível julgá-los traidores. O livro fecha com a revelação da armadilha que se montou para não liberar os que se uniram na luta contra a ditadura, conduzindo-os, dessa maneira, para a morte certa.

Longe de qualquer tratamento maniqueísta, a vilania dos regimes de opressão não se contrapõe de modo absoluto aos revoltosos, neste livro. Entre os dois pólos formam-se as “zonas cinzentas” de que falava Primo Lévi em Os Afogados e os Sobreviventes ${ }^{10}$, aquela região difusa do Lager, em que o prisioneiro se deixava 'envolver' pelas negociações com os alemães. Mas se é impossível discernir de modo absoluto as forças opostas, é certo que elas não se equivalem.Ou como disse o próprio Primo Lévi, quando trata da analogia paradoxal entre vítima e opressor: “os dois estão na mesma armadilha, mas é o opressor, e só ele, quem a preparou e a fez disparar..."11

Com o livro $K$., defrontamo-nos com uma experiência na qual a assim chamada realidade é revelada sob a forma de um abismo, marcador da ausência irremediável do corpo

\footnotetext{
${ }^{9}$ P.169.

${ }^{10}$ Levi, Primo, Os Afogados e os Sobreviventes. Rio de Janeiro: Paz e Terra, 1990. (trad.Luiz Henriques)

${ }^{11}$ Primo Levi, Os afogados e os sobreviventes. Os delitos, os castigos, as penas e as impunidades. (Trad. Luís Sérgio Henriques). São Paulo: Paz e Terra, 1990, p.10.
} 
da filha que ali deveria estar, para que o curso da vida tivesse um sentido. O livro de Bernardo Kucinski, além do testemunho de um período terrível de nossa história, é também a tão almejada lápide de Ana Rosa. 